DOI https://doi.org/10.30525/978-9934-26-146-6-21

\title{
ВИКОРИСТАННЯ СУЧАСНИХ ЦИФРОВИХ РЕСУРСІВ ДЛЯ РОЗВИТКУ ІНШОМОВНОЇ КОМПЕТЕНТНОСТІ ВІЙСЬКОВИХ ФАХІВЦІВ
}

\author{
Крикун В. Д. \\ кандидат педагогічних наук,
}

старший науковий співробітник наукового иентру мовного тестування навчально-наукового центру іноземних мов

Національний університет оборони Украӥни імені Івана Черняховського м. Київ, Украӥна

Розвиток та активне впровадження інформаційно-комунікаційних технологій в освітній простір зумовлюють переосмислення процесів реформування та модернізації системи вищої освіти відповідно до викликів сьогодення. Таке спостереження підтверджується низкою досліджень українських вчених, як-от В. Бикова, Т. Вакалюк, О. Спіріна, М. Шишкіної, які в своїх наукових розвідках зазначають, що цифрові технології сприяють створенню відкритого освітнього середовища, яке дає нові можливості для реалізації концепції безперервного навчання та проєктування індивідуальних траєкторій навчання студентів.

Міністерство освіти і науки України визначає цифровізацію освіти як один із пріоритетів розвитку можливостей дистанційного навчання у 2021 році, яка націлена на створення єдиної освітньої екосистеми, яка допоможе здобувачам освіти розвиватися, опановувати компетентності й мати постійний доступ до якісного цифрового контенту [2]. Своєю чергою, дистанційне та змішане навчання дають поштовх до активного використання цифрових технологій, які створюють необхідні умови для суб'єктів навчання як для самостійного опанування компетентностями, так і для роботи в складі команди.

Вплив цифровізації на вищу освіту через активне використання навчання в режимі онлайн яскраво висвітлений у науковій праці румунських дослідників, які завдяки SWOT-аналізу зробили цікаві висновки. Наприклад, перевагами онлайн режиму навчання були визначені такі: 1) гнучкість навчальної програми; 2) швидкий доступ до навчальних матеріалів; 3) швидке опрацювання інформації; 4) швидкий доступ до медіаресурсів: картинок, відео тощо; 5) доступ до різноманітних навчальних ресурсів та інструментів тестування; 6) заощадження ресурсів [3]. Відповідно до SWOT-аналізу, слабкими сторонами онлайн навчання іноземні фахівців визначають такі: 1) збільшення часу для опрацювання навчальних матеріалів із використанням комп’ютера; 2) підготовка до 
проведення занять в онлайн режимі займає суттєво більше часу у викладачів, аніж під час традиційного навчання; 3) відбувається порушення комунікації між викладачами та студентами через технічні причини; 4) велика залежність від мережі Інтернет та ії спроможностей. Звідси випливає, що процес цифровізації у вищій школі потребує чимало зусиль для збільшення спектру можливостей для студентів, а також для підвищення якості викладання в умовах режиму онлайн. Також необхідно націлюватися на зменшення загроз, які можуть виникнути, як-от: 1) проблеми зі здоров'ям студентів та викладачів через тривалий час проведення за комп’ютером; 2) відсутність живого спілкування може спровокувати виникнення соціальної дистанції між студентами та викладачами; 3) несанкціонований доступ до комп'ютерів може спричинити розповсюдження контенту без дозволу; 4) оприлюднення навчального матеріалу без дозволу автора призводить до порушення авторських прав [3].

Сьогодні з метою досягнення якісних перетворень у системі мовної підготовки особового складу Міністерства оборони України постає необхідність грунтовної іiі цифровізації, що забезпечить ефективне впровадження інноваційних підходів, які орієнтуються на результат розвиток іншомовної компетентності (ІК) військових фахівців Збройних Сил України задля забезпечення мовної сумісності із країнамипартнерами НАТО.

Для розвитку IК військових фахівців ефективним $є$ використання цифрового інструменту Н5Р, що полегшує створення, поширення та використання мультимедійного інтерактивного контенту, який поділяється на кілька категорій: ігри, мультимедіа, запитання та соціальні мережі. Інструмент Н5Р може бути інстальований у WordPress, Drupal, Moodle [3]. Тип контенту може бути таким: Course Presentation (презентація курсу); Interactive video (інтерактивне відео); Dialog cards (картки-діалог); Flashcards (флеш-картки); Accordion (акордеон); Drag the Words (перетягування слів) та різні види тестів. Також Н5Р можна інтегрувати у систему Moodle за допомогою спеціального плагіна, котрий можна знайти на офіційному сайті Moodle [1].

Для розвитку різних компонентів ІК у вищих військових навчальних закладах (ВВН3) також ефективним є використання Articulate 360, що є комплексом інструментів для створення онлайн-курсів. Програму можна вважати найкращим цифровим інструментом створення електронних курсів, яка місить: інструменти для інтерактивних занять, величезну кількість шаблонів і малюнків, а також надає можливість адаптувати курс під мобільні пристрої.

Отже, цифровізація освітнього процесу ВВНЗ спричинена потребою у широкому впровадженні інноваційних технологій, появою нових вимог до військових фахівців, зокрема до розвитку ІК й нового 
цифрового покоління. Завдяки використанню цифрових інструментів іншомовна підготовка військових фахівців Збройних Сил України стає більш доступною і комфортною, що вкрай важливо за умов мінімальних затрат: часових, фінансових, людських ресурсів. А для сучасного слухача ВВНЗ - це ще й інтерактивний майданчик для професійного розвитку, реалізації своєї індивідуальної траєкторії навчання та кар'єрного зросту.

\title{
Література:
}

1. Аврамчук А.М., Використання сервісу h5p для викладання мовних дисциплін. URL: : https://lib.iitta.gov.ua/709695/1/Avramchuk \%20(pdf.io).pdf дата звернення: 05.04.2021).

2. МОН Активно Долучається До Проєктів Цифрової Трансформації. 19 лютого 2021 року. URL: https://mon.gov.ua/ua/news/mon-aktivno-doluchayetsya-do-proyektivcifrovoyi-transformaciyi (дата звернення: 05.04.2021).

3. Toader, T.; Safta, M.; Titiris, C.; Firtescu, B. Effects of Digitalisation on Higher Education in a Sustainable Development Framework - Online Learning Challenges during the COVID-19 Pandemic. Sustainability. 2021. № 13, 6444. https://doi.org/10.3390/ su1311644

DOI https://doi.org/10.30525/978-9934-26-146-6-22

\section{ДИСТАНЦІЙНЕ НАВЧАННЯ В КОНТЕКСТІ РОЗВИТКУ ПРАВОВОЇ КОМПЕТЕНТНОСТІ ПЕДАГОГІЧНИХ ПРАЦІВНИКІВ ЕКОНОМІЧНИХ КОЛЕДЖІВ}

\author{
Курок Р. О. \\ кандидат юридичних наук, доцент, \\ молодиий науковий співробітник \\ лабораторії науково-методичного супроводу підготовки фахівиів \\ у коледжах і технікумах \\ Інститут професійно-технічної освіти \\ Начіональної академії педагогічних наук України \\ м. Київ, Україна
}

Аналізуючи практику впровадження інновацій в сучасній освітній діяльності в контексті розвитку правової компетентності педагогічних працівників економічних коледжів, ми можемо констатувати, що одним 